\title{
Analisis Persepsi Peserta Didik Terhadap Pembelajaran Daring Berbasis Video conference di Masa Pandemi Covid-19
}

\author{
Fatmawati ${ }^{1}$, Hafifah Namira ${ }^{*}$, Ahmad Busyairi ${ }^{1}$ \\ ${ }^{1}$ Program Studi Pendidikan Fisika, Universitas Mataram,Mataram,Indonesia
}

DOI: $10.29303 /$ goescienceedu.v2i2.136

\section{Article Info}

Received: 8 November 2021

Revised: 22 Desember 2021

Accepted: 27 Desember 2021

\begin{abstract}
Abstrak: Selama masa pandemi covid-19, sebagian besar dosen di Perguruan Tinggi melakukan proses pembelajaran dengan video conference. Namun, nampaknya pemanfaatan video conference dalam pembelajaran diyakini masih dianggap tidak lebih efektif daripada metode tatap muka secara langung. Berbagai persepsi terkait penggunaan video conference bermunculan dari berbagai kalangan. Penelitian ini bertujuan untuk mengetahui persepsi mahasiswa terhadap penggunaan video conference dalam proses pembelajaran di masa pandemi. Sampel terdiri dari 49 mahasiswa disalah satu universitas yang ada di Kota Mataram. Metode yang digunakan dalam penelitian ini yaitu metode penelitian deskriptif. Data diambil dengan menggunakan kuisioner dan wawancara. Berdasarkan hasil analisis data memperlihatkan bahwa, sebanyak $86,39 \%$ mahasiswa memiliki persepsi yang positif terhadap penggunaan video conference dalam proses pembelajaran selama masa pandemi. Rata-rata mahasiswa beranggapan bahwa dengan menggunakan video conference dapat memperlancar proses pembelajaran, lebih dapat memotivasi mahasiswa dalam belajar, dan meresa lebih efektif dalam berkomunikasi dengan dosen jika dibandingkan dengan menggunakan platform yang hanya bisa mengirim pesan dalam bentuk teks.

Kata Kunci: Pembelajaran daring; video conference; Hasil belajar; Covid-19
\end{abstract}

Abstract: During the covid-19 pandemic, most lecturers in higher education conduct the learning process with video conference. However, it seems that the use of video conferences in learning is believed to still be considered no more effective than face-to-face methods directly. Various perceptions related to the use of video conferences have sprung up from various circles. This research aims to find out the perception of students to the use of video conferences in the learning process in the pandemic period. The sample consisted of 49 students at one of the universities in Mataram City. The method used in this study is descriptive research methods. The data was retrieved using questionnaires and interviews. Based on the results of the data analysis showed that, as many as $86.39 \%$ of students have a positive perception of the use of video conferences in the learning process during the pandemic. The average student assumes that using video conferences can facilitate the learning process, can motivate students in learning, and more effective in communicating with lecturers when compared to using platforms that can only send messages in the form of text.

Keywords: Online learning; video conference; Learning outcomes; Covid-19

\section{Pendahuluan}

Selama dua tahun terakhir dunia diliputi oleh pandemi covid-19. Covid-19 merupakan nama suatu penyakit yang disebebkan oleh virus SARS-CoV2. Virus ini pertama kali muncul di Wuhan Cina, pada
Desember 2019 dan masih menjadi permasalahan hingga saat ini. Cara penularan virus ini adalah melalui tetesan kecil (droplet) yang dikeluarkan pada saat seseorang batuk atau bersin saat melakuan kontak langsung (Kemenkes, 2020). Oleh karena itu, pemerintah menghimbau masyarakat untuk menjaga

\footnotetext{
*Email: hafifahnamira00@gmail.com
} 
jarak dan menjauhi kerumunan. Banyak sektor yang terkena dampak dari adanya pandemi ini, tak terkecuali sektor pendidikan yang memang mengharuskan adanya interaksi antar manusia dalam hal ini guru dan peserta didik.

Untuk mengatasi permasalahan tersebut, di masa pandemi ini sekolah dilakukan melalui sistem daring dan bisa dilakukan di rumah (Study From Home). Hal ini secara tidak langsung tertuang dalam Surat Edaran Nomor 4 Tahun 2020 Tentang Pelaksanaan Kebijakan Pendidikan Dalam Masa Darurat Penyebaran Coronavirus Disease, salah satu kebijakannya berisi pembelajaran dari rumah melalui daring. Salah satu metode pembelajaran jarak jauh yang paling sering digunakan di tingkat perguruan tinggi adalah dengan menggunakan video conference. Video conference merupakan media komunikasi berbasis video antara dua orang atau lebih. Dengan video conference seseorang dapat bertatap muka melalui video dan membagikan layar untuk persentasi dengan mudah (Ekawardhana, et.al., 2020). Penggunakan video conference ini menjadi salah satu alternatif yang ditawarkan dunia pendidikan untuk melakukan pembelajaran demi memutus rantai penyebaran covid19. Ada berbagai macam platform media conference yang dapat digunakan antara lain zoom meeting, google meet, Microsoft teams, join.me, zoho meeting dan lain sebagainnya. Setiap platform tersebut memiliki ke khasan, kelebihan, dan kekurangannya masing-masing.

Namun, nampaknya pemanfaatan video conference dalam pembelajaran diyakini masih dianggap tidak lebih efektif daripada metode tatap muka secara langung. Berbagai persepsi terkait penggunaan video conference bermunculan dari berbagai kalangan. Hasil studi pendahuluan memperlihatkan bahwa, guru atau dosen sangat merasa kesulitan menyampaikan intruksi dan materi pembelajaran melalui video conference terutama ketika menjelaskan materi-materi sains yang menonojolkan proses penurunan matematis. Begitu juga persepsi bagi orang tua siswa yang beranggapan bahwa pembelajaran dengan menggunakan video conferen dirasa masih tidak efektif dalam memaksimalkan aktivitas belajar anak didik.

Secara empiris, penelitian terkait penggunaan video conference selama pandemi covid-19 dalam pembelajaran sudah pernah dilakukan sebelumnya oleh Ekawardhana (2020). Hasil penelitian tersebut memperlihatkan bahwa penggunaan media video conference pada pembelajaran daring sudah cukup baik namun metode yang dilakukan oleh pendidik dalam mengajar harus lebih bervariasi agar peserta didik lebih aktif dalam pembelajaran. Penelitian itu juga mengungkapkan terdapat hal negatif selama pembelajaran melaui video conference yaitu koneksi internet yang tidak stabil. Hal tersebut bertentangan dengan penelitian yang dilakukan Aminah, et.al., (2021) yakni penggunaan video conference pada pembelajaran berpengaruh terhadap hasil belajar namun tidak untuk semua mata kuliah. Jika dipandang dari jenis mata kuliah, tidak ada perbedaan rata-rata hasil belajar pada kelompok mata kuliah bersama baik pada pembelajaran video conference maupun melalui $E$ learning karena rata-rata hasil belajar pada mata kuliah sama-sama tidak bagus dan selisihnya tidak terlalu jauh.

Menurut Hikmat, et.al., (2020) evektifitas program pembelajaran tidak hanya ditinjau dari segi tingkat prestasi belajar saja, melainkan harus juga ditinjau dari segi persepsi peserta didik dan proses pembelajaran. Pendapat ini sejalan dengan pernyataan Wahyuddin dan Nurcahya (2018) yang menyatakan bahwa efektifitas pembelajaran dapat dilihat dari dua aspek yaitu yaitu: (1) Hasil belajar, yakni evaluasi akhir yang dilakukan oleh pendidik untuk mengukur tingkat penguasaan peserta didik terhadap materi pembelajaran setelah mengikuti pembelajaran tersebut. (2) proses pembelajaran, yakni kegiatan peserta didik dalam proses pembelajaran yang meliputi rasa ingin tahu, bertanya, dan menjawab persoalan yang dibahas.

Penelitian ini bertujuan untuk mengetahui persepsi peserta didik terhadap penggunaan video conference dalam proses pembelajaran selama massa pandemi covid-19. Hal ini penting dilakukan guna untuk mengetahui pandangan peserta didik terhadap suatu proses pembelajaran yang selanjutnya dapat digunakan sebagai dasar utuk melakukan evaluasi dan perbaikan.

\section{Metode}

Metode yang digunakan dalam penelitian ini adalah metode deskriptif kualitatif. Metode kualitatif merupakan prosedur penelitian yang memperoleh data deskriptif berupa kata-kata lisan maupun tertulis dari orang dan perilaku yang dialami (Moleong, 2012). Teknik pengumpulan data pada penelitian ini diambil dari data primer dengan penyebaran kuisioner atau angket yang dituangkan dalam bentuk google form. Selain itu, untuk mengetahui tanggapan mahasiswa secara mendalam, peneliti juga menggunakan wawancara langsung.

Penelitian ini dilaksanakan pada salah satu Universitas yang ada di Kota Mataram. Sampel terdiri dari 49 mahasiswa dari semester yang berbeda (semester 1, semester 3, dan semester 5). Peneliti menyusun beberapa pernyataan untuk wawancara langsung dan penyebaran angket. Pernyataan yang 
disusun terkait dengan persepsi mahasiswa terhadap pembelajaran daring berbasis video conference di masa pandemi covid-19 yang mencakup 6 aspek yaitu; (1) Keterampilan mahsiswa dalam menggunakan berbagai paltform berbasis video conference, (2) Kelancaran dalam proses pembelajaran, (3) Kemampuan mahasiswa dalam menyerap informasi jika diajarkan dengan video conference, (4) Motivasi belajar, (5) Hasil belajar, (6) Kefektifan jika digunakan selama pandemi covid-19.
Data hasil penelitian kemudian dianalisis dengan menggunakan statistik deskriptif.

\section{Hasil dan Pembahasan}

Hasil analisis data persepsi mahasiswa terhadap penggunaan video conference dalam proses pembelajaran selama massa pandemi covid-19 dapat dilihat pada Tabel 1.

Tabel 1. Hasil Analisis Data Persepsi Mahasiswa Terhadap Penggunaan Video Conference dalam Proses Pembelajaran Selama Massa Pandemi Covid-19

\begin{tabular}{|c|c|c|c|c|c|c|}
\hline \multirow{2}{*}{ No. } & \multirow{2}{*}{ Aspek } & \multicolumn{5}{|c|}{ Persentase jumlah Mahsiswa (\%) } \\
\hline & & STB & TB & $\mathrm{C}$ & B & SB \\
\hline 1 & Keterampilan penggunaan & 4,08 & 8,16 & 24,49 & 40,82 & 22,45 \\
\hline 2 & Kelancaran kegiatan pembelajaran & 4,08 & 12,24 & 32,65 & 36,73 & 14,29 \\
\hline 3 & Kemampuan dalam menyerap informasi & 4,08 & 10,20 & 28,57 & 38,78 & 18,36 \\
\hline 4 & Motivasi belajar & 4,08 & 16,33 & 36,73 & 32,65 & 10,20 \\
\hline 5 & Hasil belajar & 2,04 & 8,16 & 48,98 & 32,65 & 8,163 \\
\hline \multirow[t]{2}{*}{6} & Kefektifan jika digunakan selama pandemi Covid-19 & 4,08 & 4,08 & 26,53 & 30,61 & 34,69 \\
\hline & Total & 3,74 & 9,86 & 32,99 & 35,37 & 18,03 \\
\hline
\end{tabular}

Jika ditinjau dari aspek keterampilan mahasiswa dalam menggunakan platform berbasis video conference, terlihat bahwa secara umum rata-rata mahasiswa terampil dalam menggunakan berbagai paltform dalam proses pembelajaran. Sebanyak $87,76 \%$ mengatakan bahwa mahasiswa tidak menemukan kendala yang berarti terkait dengan kemudahan dan kepraktisan penggunaan video conference selama proses pembelajaran jarak jauh. Namun yang perlu menjadi perhatian khusus adalah adanya mahasiswa yang ternyata masing merasa kesulitan dalam mengoperasikan platform berbasis video conference terutama bagi mahasiswa-mahasiswa baru. Setelah dilakukan wawancara, rata-rata mahasiswa yang merasa kesulitan adalah mahasiswa-mahasiswa yang memang selama di SMA tidak pernah belajar dengan memanfaatkan video conference.

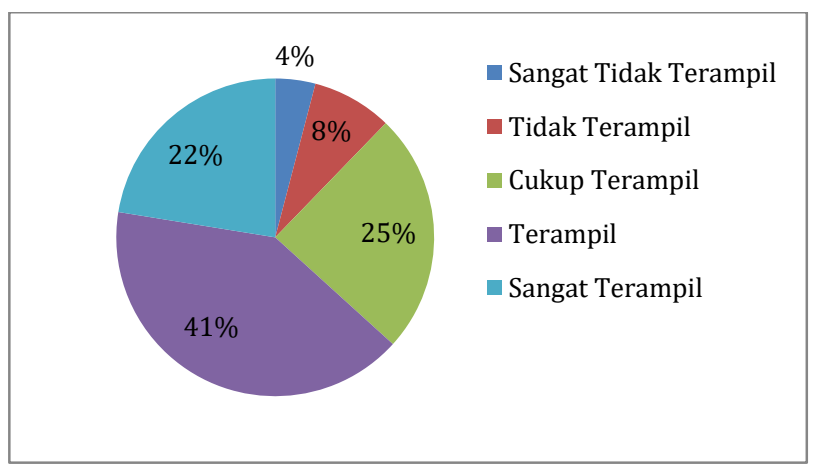

Gambar 1. Aspek penguasaan teknologi

Berdasarkan hasil angket juga menjelaskan bahwa terdapat 4 (empat) platform yang paling sering digunakan oleh dosen selama proses pembelajaran yaitu; google meet, zoom cloud meeting, Cisco Webex, dan BBB daring. Google meet merupakan platform yang paling sering digunakan selama proses pembelajaran kemudian disusul dengan zoom cloud meeting, Cisco Webex, dan yang terahit adalah BBB daring. BBB daring merupakan platform berbasis video conference yang memang dikembangkan oleh Universitas mataram untuk menunjang proses kegiatan pembelajaran di Universitas.

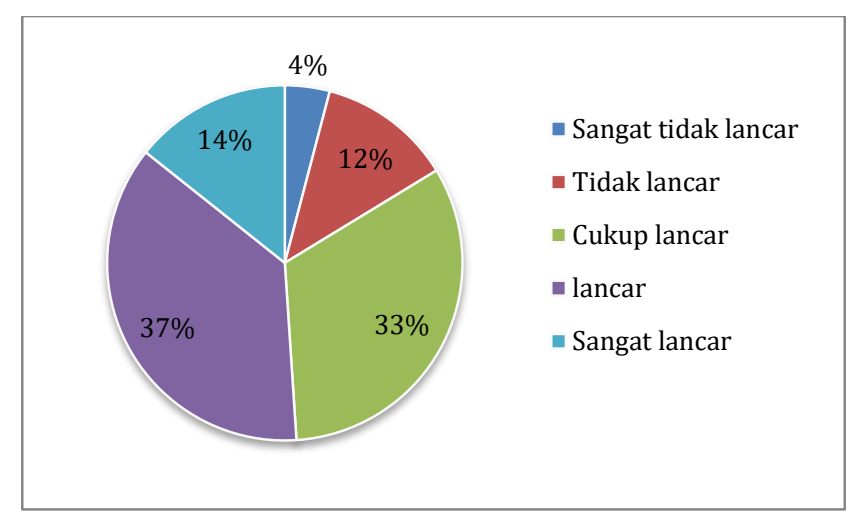

Gambar 2. Kelancaran kegiatan pembelajaran

Untuk aspek kelancaran dalam proses pembelajaran, terlihat bahwa sebanyak 32,65\% mahasiswa menyatakan bahwa proses pembelajaran dengan video conference sejauh ini cukup lancar, 36,73\% menyatakan lancar, $14,29 \%$ sangat lancar. Artinya, $85,71 \%$ mahasiswa menyatakan bahwa sejauh ini kelancaran proses pembelajaran dengan menggunakan video conference cukup baik. Namun, sebanyak 14,29\% mahasiswa mengatakan bahwa penggunakan video 
conference dalam proses pembelajaran jika ditinjau dari aspek kelancaran adalah tidak baik. Hal ini disebabkan karena terkadang dalam proses pembelajaran tiba-tiba koneksi internet terputus, suara yang terkadan kurang jelas, banyaknya ganguaan suara di luar suara yang semestinya didengar, dan faktor pengganggu lainnya.

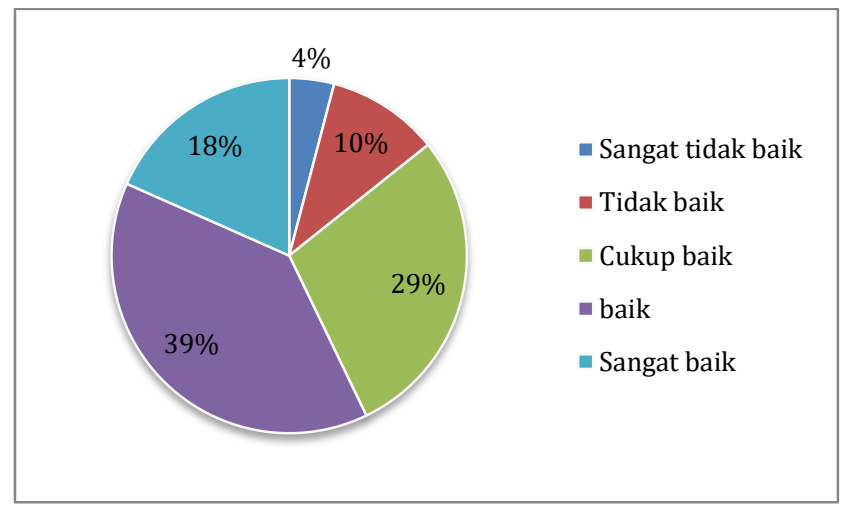

Gambar 3. Aspek kemampuan menyerap informasi

Jika ditinjau dari aspek kemampuan mahasiswa dalam menyerap informasi ketika proses pembelajaran berlangsung, terlihat bahwa sebanyak 28,57\% mahasiswa menyerap informasi dengan cukup baik, $38,78 \%$ baik, dan 18,36\% mahasiswa sangat baik. Namun, sekitar 14,10\% mahasiwa mengalami masalah dalam menyerap atau memahami informasi yang diberikan guru selama proses pembelajaran berlangsung. Berdasarkan hasil wawancara didapatkan bahwa, faktor kelancaran jaringan merupakan faktor utama yang menyebabkan mahasiswa merasa sedikit kesulitan dalam menyerap informasi dari dosen.

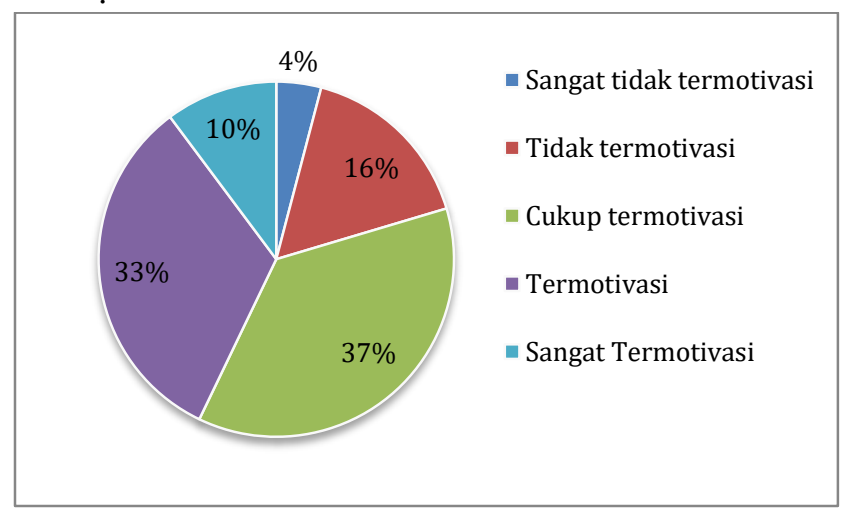

Gambar 4. Aspek motivasi dalam proses pembelajaran

Aspek yang ditinjau selanjutnya, adalah aspek motivasi belajar. Didapatkan hasil bahwa 36,73\% mahasiswa cukup termotivasi dengan proses pembelajaran dengan berbantuan video conference, kemudian termotivasi sebanyak $32,65 \%$ dan 10,20\% sangat termotivasi. Berdasarkan data yang diperoleh, dengan rendahnya motivasi mahasiswa dalam proses pembelajaran daring, menjadi hal yang perlu untuk perhatikan. Dalam hal ini peran guru pada cara mengajar sangat perlu untuk diperhatikan agar lebih kretif dan menarik sehigga dapat memotivasi mahasiswa untuk aktif mencari tau secara mandiri selama pembelaajaran daring berlangsung.

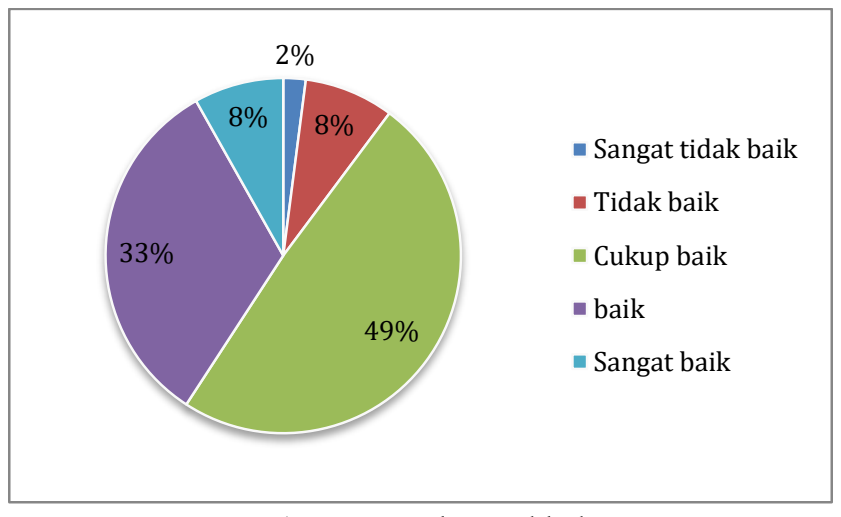

Gambar 5. Aspek Hasil belajar

Aspek selanjutnya yang akan ditinjau adalah aspek hasil belajar mahaiswa selama menggunakan media video conference pada masa pandemi. Sebanyak $89,80 \%$ hasil belajar siswa cukup baik, baik, dan sangat baik. Hanya sebanyak 10,20\% mahasiswa berpendapat bahwa pembelajaran menggunakan video conference membuat hasil belajar menjadi tidak baik. Artinya, penggunaan video conference memiliki dampak yang positif terhadap hasil belajar mahasiswa. Namun hal ini perlu dipertanyakan. Berdasarkan hasil wawancara dengan beberapa dosen mengatakan bahwa pembelajaran dengan menggunakan video conference tidak efektif dan efisien dalam proses pembelajaran.

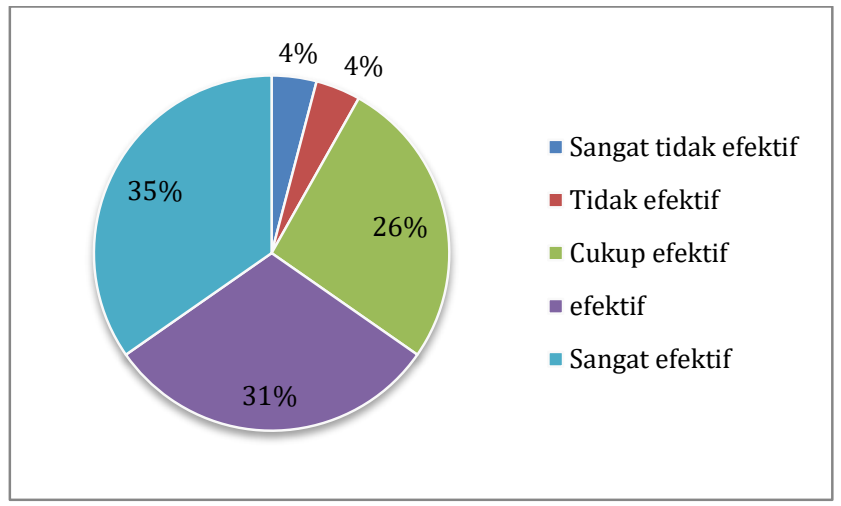

Gambar 6. Kefektifan video conference selama masa pandemic

Aspek terakhir yang ditinjau adalah aspek keefektifan penggunaan media video conference selama masa pandemi. Berdasarkan hasil analisis data seperti yang ditunjukkan pada gambar di atas memperlihatkan bahwa sebanyak 91,83\% mahasiswa mengatakan bahwa penggunaan video conferen efektif 
digunakan selama pandemi. Hanya sebesar $8,17 \%$ dari mereka mengatakan tidak efektif. Berdasarkan hasil wawancara, mahasiswa menyatakan bahwa melalui video conference ini secara tidak langsung dapat bertatap muka walaupun secara daring dan proses pembelajarannya lebih aktif dari pada menggunakan platform yang hanya melalui kirim pesan yang dibaca atau pesan suara saja.

\section{Kesimpulan}

Berdasarkan hasil analisis data memperlihatkan bahwa, mahasiswa memiliki persepsi yang positif terhadap penggunaan video conference dalam proses pembelajaran selama masa pandemi. Rata-rata mahasiswa beranggapan bahwa dengan menggunakan video conference dapat memperlancar proses pembelajaran, lebih dapat memotivasi mahasiswa dalam belajar, dan meresa lebih efektif dalam berkomunikasi dengan dosen jika dibandingkan dengan menggunakan platform yang hanya bisa kirim pesan dalam bentuk teks. Namun yang perlu menjadi perhatian adalah jaringan internet yang kurang stabil bagi mahasiswa yang tinggal di pedalaman, kuota internet yang terbatas, tidak sedikit mahasiswa yang tidak memiliki laptop sehingga belajar hanya menggunakan smart phone, dan gangguan konsentrasi selama proses pembelajaran di rumah.

\section{Ucapan Terimakasih}

Tim peneliti sangat berterima kasih kepada Himpunan Mahasiswa Pendidikan Fisika (HIMAFis) Universitas Mataram yang sudah mendanai penelitian ini melalui kegiatan lomba kepenulisan jurnal ilmiah tahun 2021.

\section{Daftar Pustaka}

Aminah, S., Radita, N., Widodo, S. (2021). Eksperimentasi Pembelajaran Daring Dengan Video conference Pada Program Studi Teknik Informatika di Masa Pandemi. Teknika, 10 (1), 3742. Doi : 10.34148/teknika.v10i1.323

Ekawardhana, Emeralda, Nattaya. 2020. Efektivitas Pembelajaran Dengan Menggunakan Media Video conference. Seminar Nasional Ilmu Terapan IV, Surabaya 7 Juli 2020, 1 (1), 1-7. Retrieved from https://ojs.widyakartika.ac.id/index.php/sniter/article/ view/218/209.

Endriyani,Eli. 2021. Analisis Efektivitas Implementasi Pembelajaran Daring Dimasa Pandemi Covid-19 Pada Siswa Sma Kelas X Se-Kecamatan Mranggen Mata Pelajaran Pjok. Journal of Physical
Activity and Sports, 2 (1), 5-7. Doi : https://doi.org/10.53869/jpas.v2i1.34

Juliya, Mira, Yusuf, H. 2021. Analisis Problematika Pembelajaran Daring Dan Pengaruhnya Terhadap Motivasi Belajar Siswa. Jurnal Genta Mulia, 12 (1), 286-289 . Retrieved from : https://ejournal.stkipbbm.ac.id/index.php/gm/article/v iewo/585/506.

Kemendikbud. 2020. Surat Edaran Mentri Pendidikan dan Kebudayaan No.4 Tahun 2020 Tentang Pelaksanaan Kebijakan Pendidikan dalam Masa Darurat Penyebaran Coronavirus Disease (Covid-19). Retrieved from https://pusdiklat.kemdikbud.go.id/sejarah-singkat/.

Khusniyah, N. L., \& Hakim, L. (2019). Efektivitas Pembelajaran Berbasis Daring: Sebuah Bukti Pada Pembelajaran Bahasa Inggris. Jurnal Tatsqif, 17(1), 21-24. DOI: https://doi.org/10.20414/jtq.v17i1.667

Mustakim. (2020). Efektivitas Pembelajaran Daring Menggunakan Media Online Selama Pandemi Covid-19 pada Mata Pelajaran Matematika. Al Asma. Journal of Islamic Education. 2(1), 12-13. Retrieved from : http://journal.uin-alauddin.ac.id

Rohmawati, A. (2015). Efektivitas Pembelajaran. Jurnal Pendidikan Usia Dini. 9(1), 15-32. Doi: https://doi.org/10.21009/JPUD.091.02

Wahyudin dan Nurcahya. 2018. Efektivitas Pembelajaran Matematika Melalui Pembelajaran Aktif Tipe Everyone Is A Teacher Here (Eth) Pada Siswa Kelas X Sma Negeri 8 Takalar. AlKhawarizmi. Jurnal Pendidikan dan Pembelajaran Matematika. 2(1), 72-105. Doi: http://dx.doi.org/10.22373/jppm.v2i1.4500

Yunitasari, R. \& Umi, H. (2020). Pengaruh Pembelajaran Daring Terhadap Minat Belajar Siswa Pada Masa Covid-19. Edukatif: Jurnal Ilmu Pendidikan. 2(3). Retrieved from : https://edukatif.org/index.php/edukatif/index 